\title{
An Exploratory Analysis of the Political Economy of Inequality and Redistribution in Advanced Democracies
}

\author{
Yoojin Lim and Hyeok Yong Kwon
}

\begin{abstract}
How have the advanced democracies reacted to increase in income inequality? How has each country's government counterbalanced to the increase in income loss and increasing risk due to rising income inequality? This paper explores the trend and patterns of income inequality in advanced democracies. Advanced democracies show a common trend of dramatic increases in income inequality since the 1980s. Cross-national differences in household income inequality persist, however. Moreover, the extent to which the government makes an effort to compensate and redistribute varies across countries greatly. Our analysis is a direct extension of Kenworthy and Pontusson (2005), but we go beyond what Kenworthy and Pontusson have shown in their analysis by analyzing the updated data that spans up until the year 2010. The use of the updated data allows us to examine the patterns of inequality and redistribution since the 2000s. This paper also examines the relationship between inequality, redistribution and social spending, utilizing the comparative political economy literature such as the Meltzer-Richard model, 'paradox of redistribution,' government partisanship, electoral systems, 'varieties of capitalism' and welfare state regime theory. This exploratory analysis suggests interesting patterns of inequality and redistribution and sheds some light on the political economy of inequality and redistribution in advanced democracies.
\end{abstract}

Key Words: inequality, redistribution, welfare state, Meltzer-Richard model, paradox of redistribution

his paper explores the political economy of income inequality and the welfare state in advanced democracies. It is well known that income inequality

\footnotetext{
*Yoojin Lim(yoojinlim@gmail.com) is a visiting scholar of Nordic Institute of Asian Studies, Denmark, specializing in political economy and welfare politics in Korea. She received a Ph.D. in political science from Yonsei University. Her recent publications include "Political Party and Transformation of Welfare Politics in South Korea" (Korean Political Party Studies, 2015) and "Party Competition and Welfare Politics of Pension Reform in South Korea" (Korean Political Science Review, 2014).

**Hyeok Yong Kwon(corresponding author, hkwon@korea.ac.kr) is Professor of Political Science at Korea University. He received his Ph.D. from Cornell University and previously taught at Texas A\&M University. His research interests are political economy, political behavior, and methodology.

The authors wish to thank Yeonsoo Park for her excellent research assistance. This work was supported by a National Research Foundation of Korea Grant funded by the Korean government (NRF2014S1A3A2044032).
}

The Korean Journal of International Studies Vol.14, No.2 (August 2016), 265-289.

http://dx.doi.org/10.14731/kjis.2016.08.14.2.265

(c) 2016 The Korean Association of International Studies 
in advanced democracies has increased since the 1980s. Against this backdrop, many studies on comparative political economy have dealt with the problem of income inequality by relating the problem to the labor market, labor market institutions, the welfare state, and democracy. Such research contrasts with earlier studies up through the late 1980s, which focused on industrial policy and labor policy from a macroeconomic point of view. After the golden age of western capitalism faded and the world experienced two waves of oil shocks in the 1970s, income inequality has consistently increased since the 1980 . Many studies in the comparative political economy literature have focused on distributive outcomes reflecting the environment (Wallerstein 1999; Rueda and Pontusson 2000; Kenworthy and Pontusson 2005; Lupu and Pontusson 2011). These studies focused on analyzing the intersection between labor market institutions and the welfare state; while labor market institutions determine the distribution of wages, it is the welfare state that corrects for the inequality that arises from the market while simultaneously socializing the diverse risks involved.

There are two stylized facts about income inequality in advanced democratic countries (Pontusson 2005). First, income inequality notably has increased in all countries since the 1980 s. Second, although all countries have experienced an increase in income inequality, there still exist differences among countries. The overall increase in inequality is explained by the common factors of globalization, de-industrialization, technological development, and the decline of labor unions. On the other hand, the differences among inequality levels are explained by domestic political institutional factors, such as differences in electoral institutions, government partisanship, and labor market institutions.

There have been debates as to whether freer capital mobility, intense competition in the global market, and the increase in imports from less developed countries due to globalization has exacerbated income inequality in advanced capitalist countries. Manufacturing-oriented industrial economies have been transformed into service industry-oriented economies, and the differences in the quality of working conditions and wages are more severe in the service sector. The exacerbation of dualization of the labor market is a phenomenon that has been occurring in tandem with globalization, de-industrialization, and technological development (Emmenegger et al. 2012). In most advanced democracies, with the exception of the Nordic countries, the decline in the labor unionization rate is widely present, and this also has contributed to wage inequality by weakening the power of labor in wage negotiations (Pontusson 2013).

Inequality created by the market is compensated for by the government's tax policies and social policies. The structure of labor market institutions contributes to the differences in wage inequality across countries. Levels of wage bargaining, 
such as those at the company, industry, or national levels, also lead to differences in wage inequality. Although it is still controversial, national-level wage bargaining is generally shown to be the lowest with respect to wage inequality (Pontusson 2005). Then how do governments react to increases in income inequality? It can be said that the welfare state protects citizens from the problems of income loss and risk. How does each country's government react to the increase in income loss and risk due to the increase in income inequality? Advanced welfare states have been faced with a welfare crisis, cutbacks, and reorganization since the 1980 . Yet, the paths that any individual welfare state followed depended on the welfare regimes, according to Esping-Andersen (1990). The ideological persuasion of the government is also considered another key determinant affecting social policy outcomes (Hibbs 1977; Kwon and Pontusson 2010). Some scholars also have argued that the electoral system affects the differences in the level of redistribution, in that proportional representation systems increase the likelihood of a victory of leftist parties, whereas majoritarian systems decrease the probability of a victory of leftist parties (Iversen and Soskice 2006).

Based on such discussions, this paper conducts an exploratory analysis on the income inequality patterns and reactions of advanced democratic welfare states since the 1980s. This paper is a direct extension of the work of Kenworthy and Pontusson (2005), which analyzed the patterns of rising inequality and government responses in affluent countries. In this paper, we go beyond what Kenworthy and Pontusson have shown in their analysis. First, we analyze more recent data spanning up to the year 2010. The use of this updated data allows us to examine the patterns of inequality and redistribution since the 2000s. Second, our exploratory analysis covers a more comprehensive list of arguments in the political economy literature than what Kenworthy and Pontusson examined.

The rest of this paper is organized into five sections. In the following section, we examine the trends and patterns of rising wage and income inequality across countries and over time. The third section analyzes whether there are differences in redistribution policies and welfare state reactions across countries and regimes, based on existing theories. The last section concludes by summarizing the results of analysis and providing implications for future research.

\section{TRENDS AND PATTERNS OF INEQUALITY IN ADVANCED DEMOCRACIES}

How does income inequality produced by the market change over time? This analysis will be conducted on 17 advanced democratic countries: Australia, 
Austria, Belgium, Canada, Denmark, Finland, France, Germany, Italy, Japan, the Netherlands, New Zealand, Norway, Sweden, Switzerland, the United Kingdom, and the United States. The Luxembourg Income Study presents a notable measurement for income inequality in advanced democratic countries. While this data provides estimates of household income, including wages and assets based on country-level research, it does not provide consistent annual data. On the other hand, the OECD provides another measurement for earnings inequality called the 90/10 ratio, measured using the rate of the top 10 percent of regular full-time workers' wages and the bottom 10 percent of regular full-time workers' wages. Although the ratio measures inequality in wages and salaries in the labor market, which does not include other assets, considering the fact that labor market dualization recently has been exacerbated makes measurement only of the wages of regular full-time workers inadequate.

In this regard, the Standardized World Income Inequality Database (SWIID) by Solt (2014) is a step forward in making cross-national comparisons possible, including annual income inequality measurements for many countries. However, the SWIID also has been criticized in that there have been discrepancies between individual country data and SWIID data. This analysis will be based on the SWIID data, while also presenting the 90/10 ratio. Figure 1 shows the changes in the levels of pre-tax household income inequality and redistribution from 1960 to 2010. It presents the average market inequality rates and average redistribution rates of the 17 countries under analysis. The upper line shows market inequality, while the lower line shows redistribution levels. Redistribution is calculated by subtracting pre-tax household income from post-tax household income. This represents how much the government counterbalanced market inequality through tax and redistribution policies. It can be observed that pre-tax household income inequality decreased from the mid-1970s and drastically increased from 1980 until 2010. The rate of increasing market income inequality has spiked dramatically since the mid-1980s, resulting in a Gini coefficient of 0.47 for the average pre-tax household income inequality rate in the 17 advanced democracies for the year 2010. Figure 1 shows that governments of advanced democratic countries tended to react to the increase of market income inequality. We also observe that levels of redistribution have on average increased together, along with the increase of pre-tax household income inequality. 
Figure 1. Market Income Inequality and Redistribution: 17 OECD Countries, 1960-2010

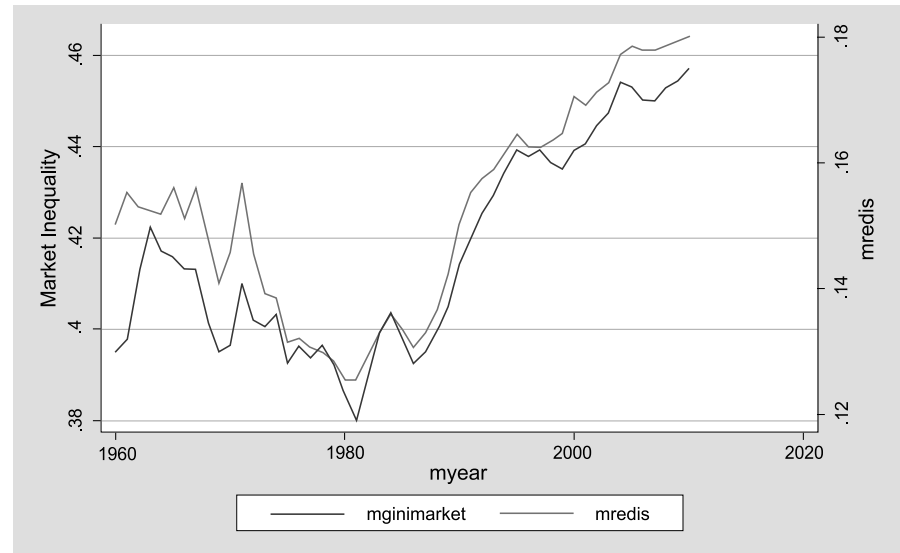

Source: Solt (2014)

Note: Market inequality (mginimarket) represents the degree of inequality of pre-tax household income (including wages and diverse assets). Redistribution (mredis) is calculated by subtracting pre-tax household income from post-tax household income, and represents how much the government corrected market inequality through tax and redistribution policies.

Table 1 shows the $90 / 10$ ratio data. Changes in the $90 / 10$ ratio can be found by comparing the oldest and new datasets. Although there are limitations to comparisons due to differences in the years of the oldest data for each country, the country with the worst levels of wage inequality during the early years was the United States, scoring 4.8 for the $90 / 10$ ratio. In other words, in 1974 those in the top 10 percent of full-time workers earned 4.8 times the amount that their counterparts in the lowest 10 percent did. Even in more recent data for the year 2012, the United States is the highest out of the 17 countries for its wage inequality levels. Its 90/10 ratio scored 6.2, an increase of a staggering 1.4 points since 1974. From higher to lower degrees of inequality, in the early years countries ranked from Australia, Canada, Japan, then the United States, while in recent years they ranked from the United States, Japan, Australia, New Zealand, United Kingdom, and so on. On the other hand, European countries scored lower levels of wage inequality compared to the Anglo-Saxon countries. In recent years, the country that scored the lowest earnings inequality using the 90/10 ratio was Denmark, scoring 2.9. Following Denmark was Norway (3.0), Finland (3.1), Belgium and the Netherlands (3.3), and Sweden and Switzerland (3.4). Interestingly, a different conclusion can be made by comparing how the 90/10 ratio changed over time. Countries with sizable increases in earnings inequality ranked as follows: the 
United States (1.4), Japan (1.2), the United Kingdom (0.9), Sweden (0.8), and New Zealand (o.8).

Table 1. Changes in 90/10 Ratio by Country

\begin{tabular}{l|l|l|l|l|l}
\hline \multirow{2}{*}{ Country } & \multicolumn{2}{|l|}{ Initial Data Year } & \multicolumn{2}{l}{ Recent Data Year } & \multirow{2}{*}{ Difference } \\
\cline { 2 - 5 } & $\mathbf{9 0 / 1 0}$ Ratio & Year & $\mathbf{9 0 / 1 0}$ Ratio & Year & \\
\hline Australia & 4.0 & 1995 & 4.4 & 2012 & 0.4 \\
\hline Austria & 3.2 & 2004 & 3.5 & 2012 & 0.3 \\
\hline Belgium & 3.3 & 2004 & 3.3 & 2012 & 0 \\
\hline Canada & 4.1 & 1976 & 4.1 & 2012 & 0 \\
\hline Denmark & 2.8 & 1985 & 2.9 & 2011 & 0.1 \\
\hline Finland & 2.6 & 1986 & 3.1 & 2012 & 0.5 \\
\hline France & 3.4 & 1996 & 3.6 & 2011 & 0.2 \\
\hline Germany & 3.0 & 1985 & 3.6 & 2011 & 0.6 \\
\hline Italy & 3.9 & 1984 & 4.3 & 2012 & 0.4 \\
\hline Japan & 4.0 & 1985 & 5.2 & 2009 & 1.2 \\
\hline Netherlands & 2.8 & 1977 & 3.3 & 2012 & 0.5 \\
\hline New Zealand & 3.4 & 1985 & 4.2 & 2011 & 0.8 \\
\hline Norway & 2.8 & 1986 & 3.0 & 2011 & 0.2 \\
\hline Sweden & 2.6 & 1975 & 3.4 & 2011 & 0.8 \\
\hline Switzerland & 3.4 & 2009 & 3.4 & 2011 & 0 \\
\hline United Kingdom & 3.2 & 1975 & 4.1 & 2010 & 0.9 \\
\hline United States & 4.8 & 1974 & 6.2 & 2012 & 1.4 \\
\hline
\end{tabular}

Source: OECD

Table 2 shows pre-tax household income inequality, disposable household income inequality, and the level of redistribution represented by subtracting the first two measures, using data from around 1979 and comparing it to more recent data. The year of 1979 was important because this was when the advanced capitalist countries faced new challenges after experiencing two waves of oil shocks. Countries that showed the greatest levels of redistribution were Sweden (0.248), Denmark (0.223), Austria (0.189), and Finland (0.167). During 2009-2010, the countries ranked from Denmark (o.273), Germany (0.252), Sweden (0.230), Finland (0.216) to France (0.215). Not only Anglo-Saxon countries, such as the United States, Canada, Australia and New Zealand, but also Japan showed the lowest levels of redistribution. 
Table 2. Changes in Pre-tax Household Income Inequality and Redistribution

\begin{tabular}{l|l|l|l|l|l|l|l|l}
\hline \multirow{2}{*}{ Country } & \multicolumn{2}{|c|}{ Around 1979 } & \multicolumn{2}{l}{ Recent Data } \\
\cline { 2 - 8 } & Year & $\begin{array}{l}\text { Market } \\
\text { Income }\end{array}$ & $\begin{array}{l}\text { Disposable } \\
\text { Income }\end{array}$ & $\begin{array}{l}\text { Redistri- } \\
\text { bution }\end{array}$ & Year & $\begin{array}{l}\text { Market } \\
\text { Income }\end{array}$ & $\begin{array}{l}\text { Disposable } \\
\text { Income }\end{array}$ & $\begin{array}{l}\text { Redistri- } \\
\text { bution }\end{array}$ \\
\hline Australia & 1979 & 0.351 & 0.258 & 0.093 & 2010 & 0.472 & 0.339 & 0.133 \\
\hline Austria & 1981 & 0.511 & 0.322 & 0.189 & 2010 & 0.475 & 0.274 & 0.201 \\
\hline Belgium & 1979 & 0.254 & 0.224 & 0.030 & 2010 & 0.378 & 0.251 & 0.127 \\
\hline Canada & 1979 & 0.367 & 0.282 & 0.086 & 2009 & 0.428 & 0.314 & 0.114 \\
\hline Denmark & 1979 & 0.488 & 0.265 & 0.223 & 2010 & 0.544 & 0.270 & 0.273 \\
\hline Finland & 1979 & 0.383 & 0.216 & 0.167 & 2010 & 0.471 & 0.255 & 0.216 \\
\hline France & 1979 & 0.413 & 0.293 & 0.120 & 2010 & 0.504 & 0.289 & 0.215 \\
\hline Germany & 1979 & 0.416 & 0.257 & 0.159 & 2010 & 0.555 & 0.303 & 0.252 \\
\hline Italy & 1979 & 0.443 & 0.328 & 0.115 & 2010 & 0.436 & 0.326 & 0.111 \\
\hline Japan & 1979 & 0.357 & 0.317 & 0.041 & 2010 & 0.370 & 0.305 & 0.065 \\
\hline Netherlands & 1979 & 0.389 & 0.252 & 0.137 & 2010 & 0.461 & 0.268 & 0.193 \\
\hline New Zealand & 1979 & 0.370 & 0.265 & 0.105 & 2007 & 0.438 & 0.325 & 0.112 \\
\hline Norway & 1979 & 0.377 & 0.223 & 0.154 & 2010 & 0.404 & 0.222 & 0.182 \\
\hline Sweden & 1979 & 0.469 & 0.220 & 0.248 & 2010 & 0.449 & 0.219 & 0.230 \\
\hline Switzerland & 1980 & 0.446 & 0.313 & 0.134 & 2009 & 0.465 & 0.302 & 0.163 \\
\hline United Kingdom & 1979 & 0.411 & 0.270 & 0.141 & 2010 & 0.517 & 0.365 & 0.151 \\
\hline United States & 1979 & 0.406 & 0.301 & 0.105 & 2010 & 0.462 & 0.360 & 0.102 \\
\hline
\end{tabular}

Source: OECD

Examining Tables 1 and 2, it is notable that pre-tax household income inequality in all countries, including Sweden, Norway, Finland, and Belgium, increased since 1980. While the earnings inequality level for (regular) individual workers is relatively lower than other countries, pre-tax household income inequality levels showed unstable and relatively high values. This has been attributed to the collapse of full employment since the 1980s, and the growth in both full- and parttime employment has failed to match this increase in unemployment. That is, the access to employment has been stagnant in northern European countries, and this has led to increases in household income inequality (Kenworthy and Pontusson 2005). The argument seems convincing considering the fact that countries that showed high increases in employment rates since the late 1980s, such as the Netherlands and the United States, showed relatively lower levels of household income inequality. In other words, employment growth was attained to create or give an incentive to make part-time jobs, leading to a reduction in 
inequality levels on the household-level. It is also interesting to note that when analyzing trends in pre-tax household income inequality and redistribution levels by country, the Anglo-Saxon countries of the United Kingdom, the United States, Australia, and New Zealand recently have deviated from the pattern of redistribution levels corresponding to inequality levels. On the other hand, continent European countries, such as France, the Netherlands, Germany, and Belgium, have shown relatively higher rates of correspondence between inequality and redistribution. How can we account for these trends and patterns of wage and income inequality in advanced democracies? What explains cross-national variations in rising inequality and redistribution efforts? In the next section we examine several political economy explanations to account for such questions.

\section{THE POLITICAL ECONOMY OF INEQUALITY AND REDISTRIBUTION}

\section{MELTZER-RICHARD MODEL AND THE PARADOX OF REDISTRIBUTION} One of the traits of democratic governments is to respond to the interests and demands of citizens. Accordingly, we can predict that the welfare state would react according to increases in income inequality. Two theoretical arguments are in competition (Kenworthy and Pontusson 2005, 456-458). The first is the Meltzer-Richard model based on the median voter theorem (Meltzer and Richard 1981). According to this model, government spending provides equal amounts of transfer to each individual. This government spending is provided by a proportional income tax in which taxes grow with market income. This model intuitively draws the conclusion that those with low incomes stand to gain more and lose less with the increase in government spending compared to those with higher incomes. In a one-dimensional electoral competition, support for government spending is determined by the distance between the income of the median voter and the mean income of all voters. The greater the inequality, the more the gap between the income of the median voter and the mean income increases - the median income is far less than the mean income - and support for greater government spending and redistribution rises accordingly. Therefore, the MeltzerRichard model implies that the higher is income inequality, the greater will be the government's efforts to promote redistribution.

The other is the Moene-Wallerstein model (Moene and Wallerstein 2001; 2003), which revised the Meltzer-Richard model. Moene and Wallerstein pointed out that actual empirical data showed a negative correlation between income inequality and government spending. The more unequal a country was, the less 
the government spent on social welfare. In order to explain this 'paradox of redistribution,' Moene and Wallerstein focused on the fact that a government's social welfare spending included the function of 'insurance' and 'redistribution' at the same time. According to the Moene-Wallerstein model, as income increases, the demand for insurance also increases, holding risk constant. Hence, if the average income does not change as inequality increases, the median voter's income decreases, dragging with it the median voter's demand for social insurance.

Figure 2.The 90/10 Ratio and Redistribution
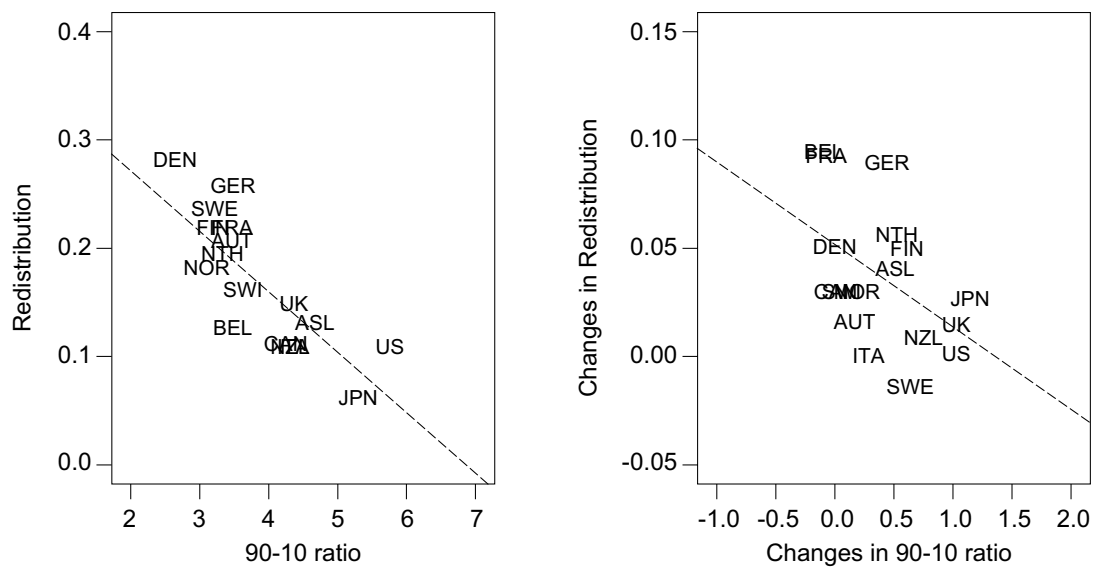

Based on this theoretical background, we conducted an analysis of the relationship between income inequality, on the one hand, and redistribution and welfare spending, on the other. Figure 2 presents the relationship between earnings inequality shown with 90/10 ratio and redistribution. The 90/10 ratio was used for each country in the year 2008, while redistribution levels were represented by data for the year 2010. Figure 2 shows the paradox of redistribution. Countries that scored high in income inequality, such as Japan, the United States, Australia, the United Kingdom, and New Zealand, showed lower levels of redistribution, while countries with lower levels of inequality, such as the Nordic countries, scored the highest levels of redistribution. The empirical data is in contrast to the argument presented by the Meltzer-Richard model, which argues that as inequality increases, the median voter who stands to gain from redistribution policies will support them, leading to more redistribution. Since the Meltzer-Richard model can be said to deal with the relationship between the increase in inequality and the increase in redistribution, the panel on the right-hand side of Figure 2 
shows the changes in wage inequality and redistribution. Even when measuring the change, the paradox of redistribution is observed.

The relationship between earnings inequality measured in 90/10 ratio and social spending is presented in Figure 3. As with Figure 2, the figure shows that the size of social welfare spending is smaller in countries with higher wage inequality, whereas the size of social welfare spending is higher in countries with lower wage inequality. Again, it supports the paradox of redistribution. Not only does the right-hand panel of Figure 3 show the relationship between an increase in inequality and an increase in welfare spending, but also the size of welfare spending grows where income inequality grows. Although the slope of the regression is rather flat, the graph shows a positive correlation between an increase in inequality and an increase in social spending, which corresponds to the MeltzerRichard model's predictions. In Figure 2, increases in earnings inequality and increases in redistribution showed a negative correlation, but in Figure 3, increases in earnings inequality and increases in social welfare spending showed a positive correlation.

Figure 3.The 90/10 Ratio and Social Welfare Spending
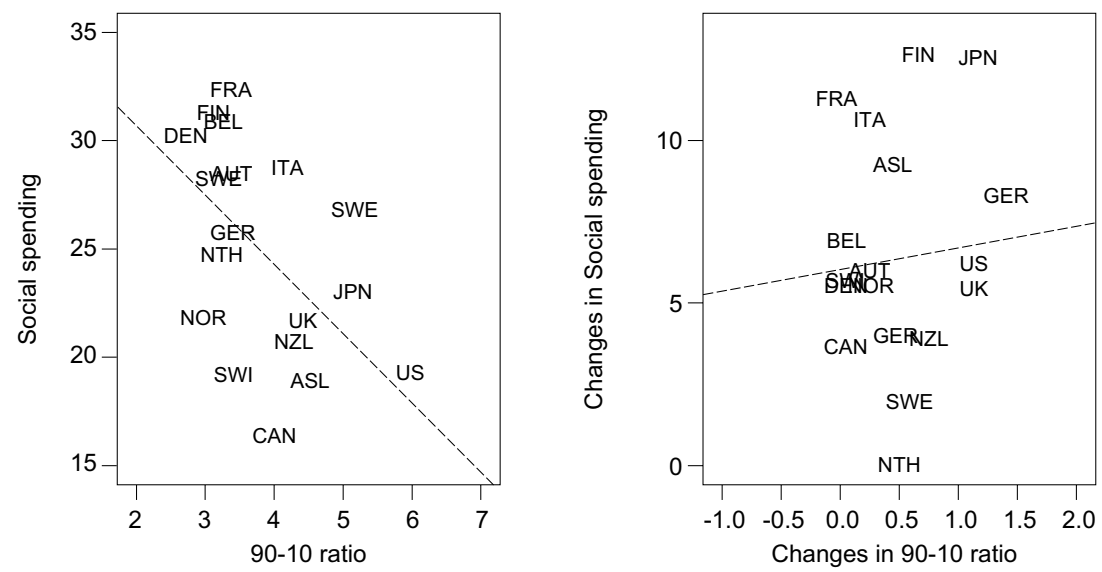

As mentioned, earnings inequality measured with the $90 / 10$ ratio includes only full-time workers. Thus, there are limitations to the 90/10 ratio fully capturing income inequality that arises from the labor market. It is well known that as the labor market undergoes dualization, and fragmentation deepens, the wage gap between insiders based on stable employment contracts and outsiders, which include diverse types of non-regular/non-standard workers and unemployed 
laborers, increases (Emmeneger et al. 2012). Many studies already have been conducted on the political divide between insiders and outsiders in labor markets (Rueda 2005; 2007). Moreover, considering the fact that the basic economic unit of society is the household, and that not only wages but diverse types of income such as assets exhibit a greater gap in inequality, it is meaningful to use measurements such as the pre-tax household income inequality index to measure the relationship between income inequality, redistribution, and the welfare state.

Figure 4. Market Income Inequality and Redistribution
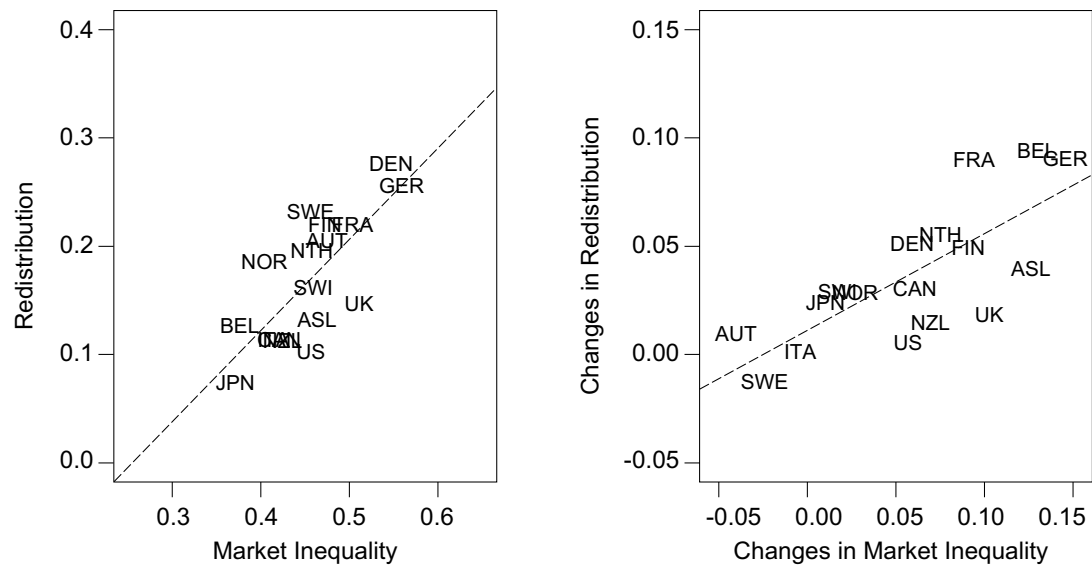

Figure 4 shows the relationship between pre-tax household income inequality and redistribution. The figure shows a pattern corresponding to the arguments presented by the Meltzer-Richard model. When using the left panel's level index, even with the right panel's change index, income inequality shows a positive correlation with redistribution. According to the left panel, Denmark and Germany, which have a high level of pre-tax household income inequality, show the highest level of redistribution, while countries such as Belgium and Japan with lower levels of income inequality seem to redistribute less. As shown in the right panel, it seems that increases in redistribution occurred more substantially in countries where income inequality increased more. In Figure 4, we can observe that countries with similar household income inequality levels, such as Sweden, Finland, the Netherlands, Switzerland, Australia, and the United States, show differences when it comes to redistribution levels. Sweden redistributes the most, followed by Finland and the Netherlands, with Australia and the United States showing the lowest levels of redistribution. 
It is interesting to note that the patterns in Figure 4 contrast with those presented in Figure 2. In other words, while the relationship between the full-time earnings inequality index (90/10 ratio) and the level of redistribution corresponds with the phenomenon of the paradox of redistribution, showing a negative correlation, the relationship between pre-tax household income inequality (Gini coefficient) and the level of redistribution shows a positive correlation, corresponding to the predictions of the Meltzer-Richard model. The following may explain such a phenomenon. The earnings inequality index with only full-time workers has clear limitations in representing inequality levels, considering the fact that the societies in question have been experiencing de-industrialization, and that labor market outsiders are increasing with the growth of temporary, part-time, and non-standard employment and the unemployed. The level of redistribution was measured by looking at the pre- and post-tax change in household income Gini coefficients and showed a weak or negative correlation with earnings inequality of full-time workers. It seems that the traditional breadwinner model, which assumes that a household depends on a full-time worker working in manufacturing, does not correspond well with indices that represent a country's income inequality levels.

Figure 5. Market Income Inequality and Social Welfare Spending
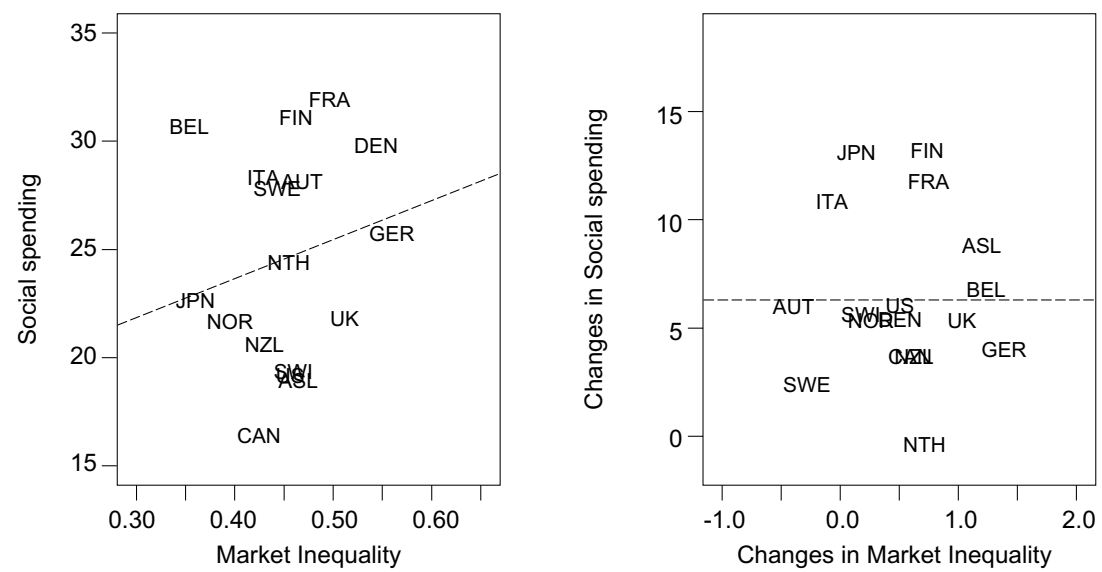

Figure 5 shows the relationship between pre-tax household income inequality and social welfare spending. In general, the higher the income inequality, the bigger is the size of welfare spending. However, as seen in the right-hand panel, an increase in income inequality does not necessarily lead to an increase in social 
welfare spending.

\section{GOVERNMENT PARTISANSHIP, REDISTRIBUTION, AND THE WELFARE STATE}

The Meltzer-Richard model presents the argument that under majoritarian electoral systems, when two parties compete, the median voter becomes the pivotal voter, thus translating the policy preferences of the median voter into actual policy outcomes. The prediction that an increase in inequality leads to an expansion of redistribution policies is based on the mechanism of the median voter's change in income and policy preferences due to an increase in inequality. On the other hand, there are arguments that there is a third factor that affects both inequality levels and redistribution levels (Korpi 2006). Power resource theory is one such argument. One of the implications of the power resource theory is that the more politically mobilized are the power resources of labor, the lower is the income inequality level and the greater is the welfare state's efforts to manage inequality (Korpi 1983; Bradley et al. 2003). The better organized is labor and the more centralized the union structure - as much as the negative externalities of collective action can be internalized - the more likely voluntary wage restraints and wage compression will be accomplished. This leads to lower income inequality. Furthermore, once labor becomes politically mobilized and a political party representing the interests of labor maintains its position as a prominent competing party in electoral politics - even becoming the governing party - the greater is the possibility that the institutions and policies of redistribution and social policies will expand.

Many earlier studies explained the relationship between inequality and redistribution by using the Meltzer-Richard model as the central mechanism. Notably, Iversen and Soskice (2006) found that in countries with a majoritarian system, the more likely it was that the center-right party would seize power, leading to less effort to redistribute. In countries with proportional representation systems, the more likely it was that the government would become center-left, leading to greater effort at redistribution. Iversen and Soskice's argument is in line with the Meltzer-Richard model considering that, depending on the electoral system, it is crucial whether or not the median voter as the pivotal voter ends up siding with the center-left coalition (PR) or the center-right coalition party (majoritarian system); on the other hand, the position of Iversen and Soskice also is in line with the government partisanship theory considering that, depending on the party coalition dynamics determining the ruling party, government partisanship affects the differences in redistribution policy results.

The theory of government partisanship follows the logic that the ideological 
persuasion of the governing party leads to differences in policy outcomes. This is because the policy preferences of the governing party's core constituency leads to policy results. For example, since the core constituency of a rightist party is highincome property owners who fear the decline of equity caused by inflation, rightist parties tend to focus on controlling inflation when forming macroeconomic policies. On the other hand, leftist parties respond to the economic interests of workers and lower income groups, their core constituencies, by reducing the unemployment rate as much as possible (Hibbs 1977). Redistribution and social policies can also be explained in a similar fashion (Garrett 1998; Kwon and Pontusson 2010). Based on these discussions, this section examines the empirical relationship between government partisanship, redistribution, and social policies.

Figure 6. Leftist Government Partisanship, Social Spending, and Redistribution
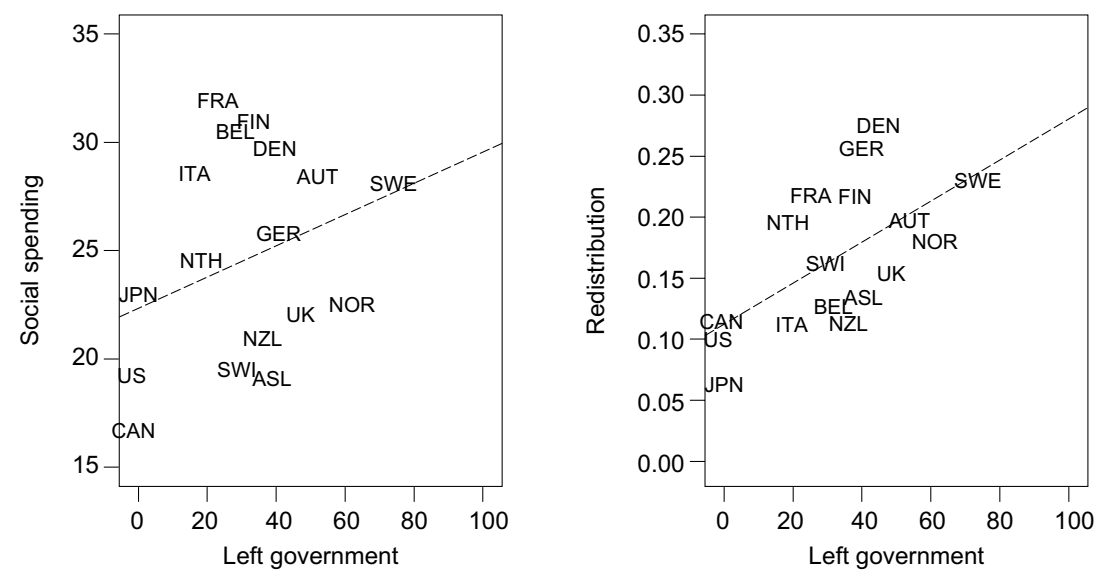

Source: Swank (2015)

Note: Government partisanship is the ratio of cabinet members from leftist parties out of all cabinet members in the period 1960-2010.

Figure 6 shows the relationships between leftist government partisanship and welfare spending (left panel) and redistribution (right panel). Government partisanship was measured by using the average value of the ratio of cabinet members from leftist parties out of all cabinet members during the period 1960-2010. This measurement is based on the logic that, in a country where the leftist government takes office more often, a leftist hegemony forms and influence over policies will be exerted based on leftist norms (Huber and Stephens 2001). The social spend- 
ing and redistribution levels data are from 2013-4 and 2012, respectively. In Figure 6, as power resource theory and 'parties do matter' approaches predict, the relationship between leftist government partisanship, welfare spending, and redistribution all show positive relationships. The pattern is clearer with redistribution levels compared to social spending levels. The slope of the regression prediction line is steeper. However, such an interpretation must be done carefully because this is a bivariate regression using a limited number of cases. There also have been debates on whether, since the 1990s, the effects of leftist government policy have been curbed due to various factors such as changes in economic structure and the economic environment (Allan and Scruggs 2004).

However, if we look at the pattern presented in Figure 6, the effect of government partisanship does seem to be at work. In countries where rightist parties were in office for a long time - or where leftist parties were nonexistent, such as the United States, Canada, and Japan - redistribution and social spending levels were low, while in countries where leftist parties were in office more often, such as Sweden and Norway, higher levels of redistribution and social spending were found. When restricting the analysis to more recent data on redistribution and social spending, those with the highest levels were countries such as Denmark, France, Finland, Belgium and Germany. Except for Denmark and Finland, most continental European countries showed the highest levels of redistribution and social spending.

Korpi and Palme (2003) and Allan and Scruggs (2004) have argued that the influence of structural factors, such as economic recession and globalization since the 1980 s, made it impossible to expand the welfare state when leftist governments held office, while the welfare state and the budget for redistribution policies shrunk under conservative governments. Restrictions on government tax policies caused by freer capital mobility, financial pressures caused by slowing economic growth and ageing populations, were problems shared by all advanced democratic countries, and these pressures have restricted the policy prescriptions of leftist governments. On the other hand, changes in the economic environment have provided good justification for the policies that have been pursued, such as welfare state cutbacks, tax cuts, and market-oriented policies. Thus, compared to how the relationship between leftist government and the expansion of redistribution and social policy became unclear since the 1990s, the relationship between rightist governments and the reduction in redistribution and social policy initiatives have become predictable (Allan and Scruggs 2004). 
Figure 7. Rightist Government Partisanship, Social Spending, and Redistribution
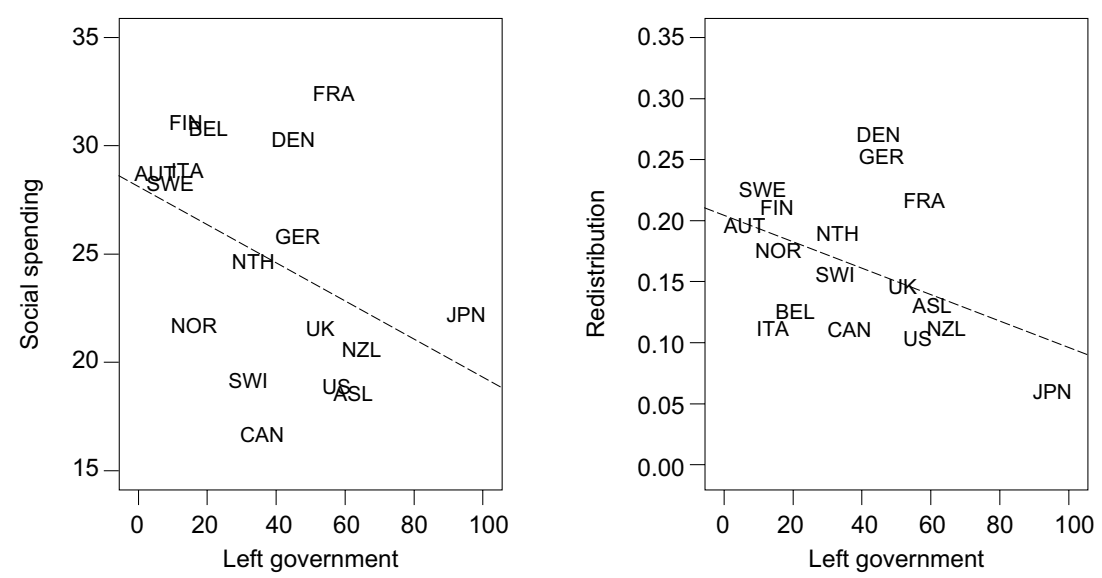

Source: Swank (2015)

Note: Government partisanship is the ratio of cabinet members from rightist parties out of all cabinet members in the period 1960-2010.

Figure 7 shows the relationships between rightist government partisanship, welfare spending, and redistribution. The figure corresponds to the pattern argued by the research of Korpi and Palme (2003) and Allan and Scruggs (2004). Thus, when rightist government partisanship was strong, the level of social spending and redistribution were both low.

\section{ELECTORAL SYSTEM, REDISTRIBUTION, AND THE WELFARE STATE}

This section provides analysis of whether inequality, redistribution, and social policy outcomes are affected by differences in the electoral system. We categorized the 17 advanced democratic countries into two groups: those with proportional representation electoral systems and those with majoritarian or mixed electoral systems, and then analyzed the difference in their impact on inequality, redistribution, and social policy outcomes. Countries with proportional representation systems are Austria, Belgium, Denmark, Finland, the Netherlands, Norway, Switzerland, and Sweden. Those with majoritarian or mixed electoral systems are Australia, Canada, France, Germany, Italy, Japan, New Zealand, the United Kingdom, and the United States. Keeping in mind that the cases for both proportional and majoritarian/mixed categories are small - eight and nine countries, respectively - this section will look into the relationship between inequality and policy outcomes.

As Iversen and Soskice (2006) argued, electoral systems affect the dynamics of 
party coalition-building and who becomes the ruling party. They also provide a clue to the question of why some countries redistribute more than others. We do not analyze here whether electoral systems affect the patterns of inequality and redistribution because Iversen and Soskice have already provided the theoretical mechanism and empirical observation that countries with proportional representation systems tended to redistribute more than their majoritarian counterparts. On average, countries with proportional representation systems redistribute more and spend more on social welfare. However, it is not well known how the relationship between levels of inequality and levels of redistribution and social spending differ under the two types of electoral systems.

Figure 8. Electoral System, Inequality, and Redistribution
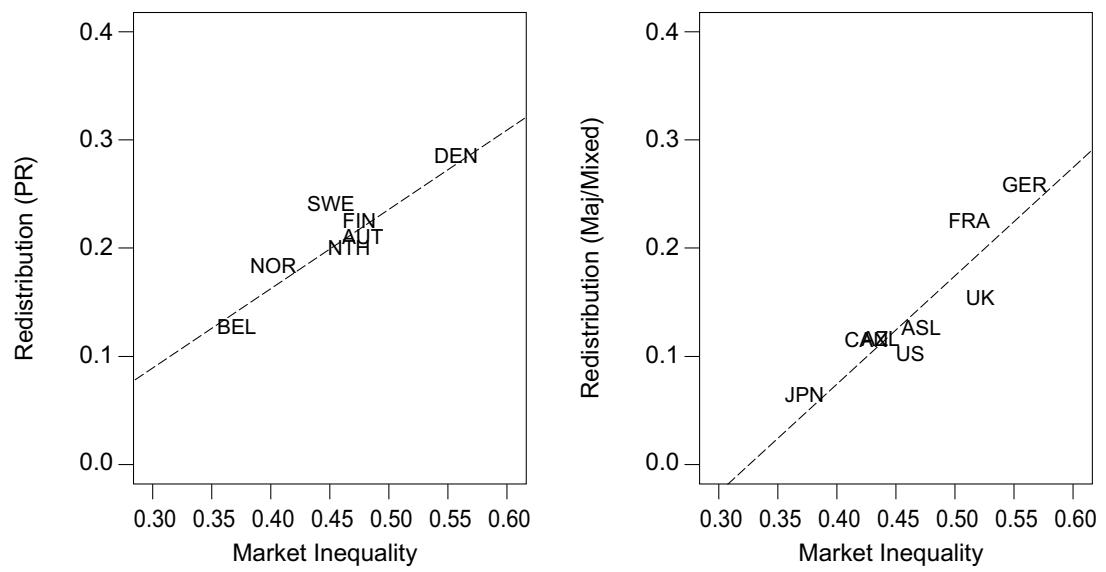

Note: The left panel includes countries with proportional representation as their electoral system, while the right panel includes countries with majoritarian/mixed electoral systems.

Figure 8 shows the relationship between pre-tax household income inequality and redistribution divided into the two aforementioned types of electoral systems. The left panel includes countries with proportional representation electoral systems, while the right panel includes countries with majoritarian/mixed electoral systems. The relationship between pre-tax household income inequality and redistribution shows a positive correlation for both types of electoral systems. It seems that there are no systematic differences caused by the type of electoral system.

Figure 9 presents an analysis of the relationship between inequality and social spending divided by the two types of electoral systems. Both electoral systems 
show a positive correlation between pre-tax household income inequality and social spending. As with Figure 8, the patterns in Figure 9 show that it is difficult to find a systematic difference caused by the effects of electoral systems on inequality and social policy outcomes.

Figure 9. Electoral System, Inequality and the Welfare State
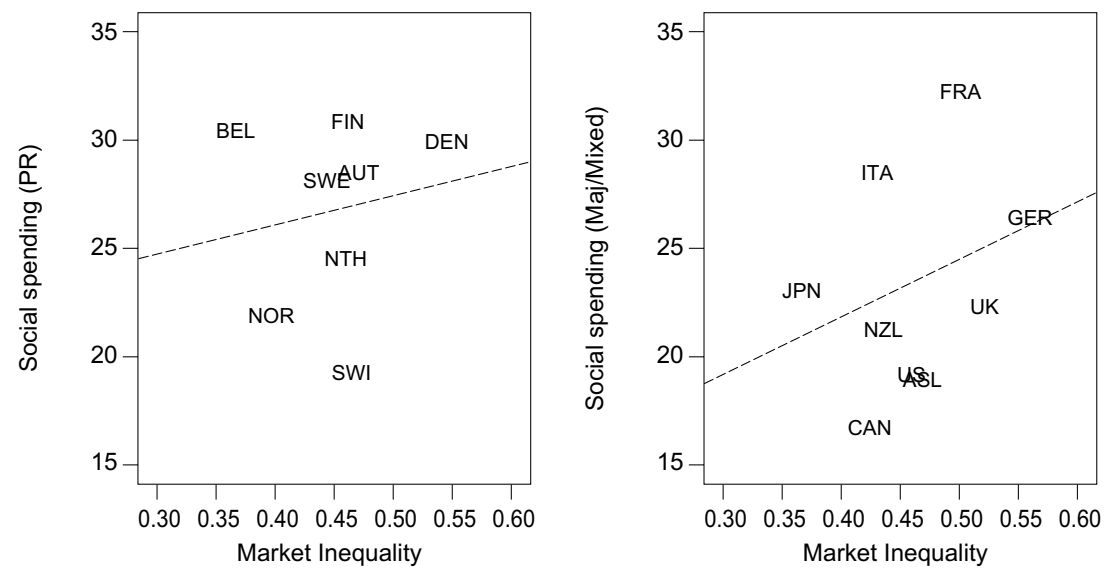

Note: the left panel includes countries with proportional representation as their electoral system while the right panel includes countries with majoritarian/mixed electoral systems.

We can postulate two insights from these results. First, electoral systems are not correlated with inequality and redistribution or social policies. The reason why electoral systems are treated as important in political economy research is because they constrain and give incentives to the preferences or actions of parties and politicians. As the neo-institutionalist approach argues, political institutions create and shape the agent's incentive structure. Hence, it can be said that electoral systems affect the agent's incentive structure, thus affecting the relationship between inequality and redistribution through the dynamics of electoral politics. There are a number of parameters that hinder us from finding a systematic difference between the countries with proportional representation systems and those with majoritarian/mixed electoral systems. Second, the relationships between market income inequality and redistribution and social policy outcomes could be more accurately explained by the political economy regime or welfare state regime rather than by political institutional factors. Of course, a correlation exists between electoral systems, political economy, and welfare state regimes. For instance, there certainly is a selective affinity between coordinated market 
economies, or social democratic welfare state regimes, and the proportional representation system. Similarly, there is a close relationship between liberal market economies, or liberal welfare state regimes, and majoritarian electoral systems. However, theoretically, more macro-factors, such as the type of political economy regime or welfare state regime, may be more influential than specific political institutional arrangements, such as electoral systems.

\section{VARIETIES OF CAPITALISM AND THE WELFARE STATE REGIMES}

This section examines the relationship between inequality and social policy outcomes by looking at political economy regimes based on the framework of the 'varieties of capitalism,' while also discussing the welfare state regimes presented by Esping-Andersen (1990). First, this section evaluates the relationship between inequality, the welfare state, and redistribution by categorizing countries into two groups based on the 'varieties of capitalism' framework, excluding countries such as Italy, France, Japan and Switzerland, which have economic systems that are difficult to categorize. There exist two distinct systems of political economy (Hall and Soskice 2001): a 'high inequality-small welfare state' group comprising such liberal market economies (LMEs) as the United States, the United Kingdom, Canada, Australia, and New Zealand, and a 'low inequality-big welfare state' group comprising such coordinated market economies (CMEs) as Germany, the Netherlands, Belgium, and the Nordic countries. In coordinated market economies, the bargaining power of labor is stronger and wage restraints can be achieved, while employers create political, legal, and institutional mechanisms to provide wage protection, employment protection, and unemployment protection in order to maintain the supply of firm-specific or industry-specific skills required for production. Furthermore, in proportional representation electoral systems that have a selective affinity for a coordinated market economy, leftist political parties have a relatively higher chance of becoming the governing party. Since those parties tend to focus on public education and the expansion of welfare policies, the combination of low inequality and large welfare state spending can be observed (Estevez-Abe et al. 2001; Iversen and Soskice 2009). The combination of high inequality with a smaller welfare state found in liberal market economies can be explained by opposite causal mechanisms.

Figure 10 shows the relationship between income inequality and redistribution in coordinated market economies (left panel) and liberal market economies (right panel). As can be observed in the two groups of countries, the level of redistribution in liberal market economies is far lower than their counterparts. However, the pattern of positive correlation between income inequality and redistribution is shared by both groups of countries. It is also shown that countries with higher 
inequality levels - as measured by pre-tax household income - redistribute more. Such a pattern is observed in both liberal market economies and coordinated market economies.

Figure 10. Varieties of Capitalism, Inequality and Redistribution
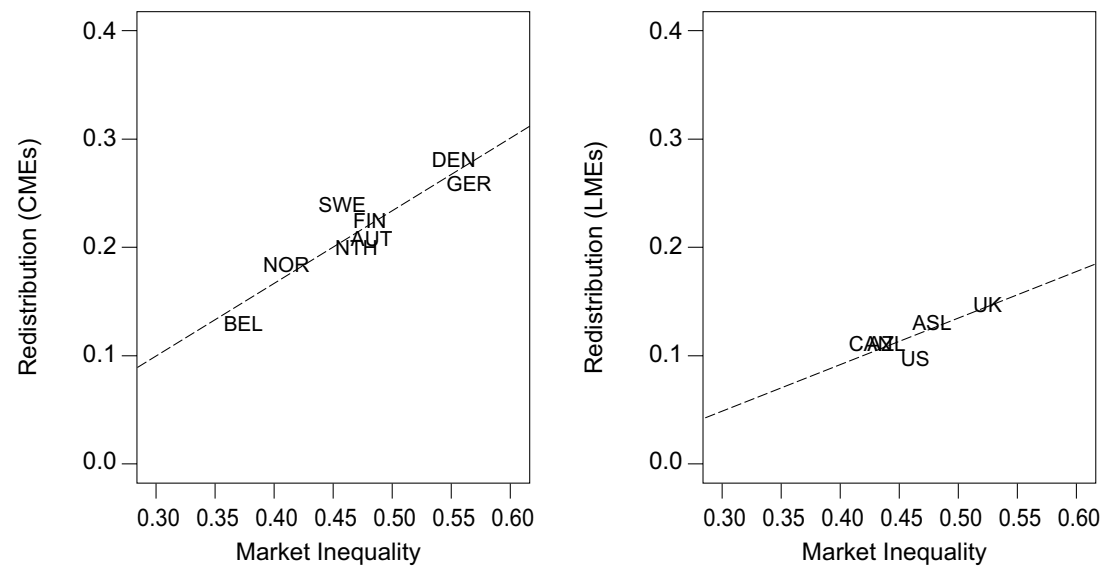

Esping-Andersen categorized welfare states into three regimes: liberal, conservative, and social democratic welfare state regimes, based on 'de-commodification' and 'stratification' (Esping-Andersen 1990; 1999). Also, Esping-Andersen considered the role of market and family in welfare spending through the concept of a 'regime,' and this conceptualization became the theoretical framework to explain the reorganization of welfare states since those states began experiencing diverse socioeconomic changes. In liberal welfare state regimes, welfare is managed in the form of social assistance based on strict means tests and income investigations. Thus, in liberal welfare state regimes, receiving welfare is not only shameful in itself but, since the inequality of poverty among those who rely on state welfare is expected to continue, the state forces individuals to purchase welfare, such as private insurance and private services, by activating the market. Hence, in liberal welfare state regimes, the de-commodification effect of welfare is minimized by maintaining the class-political dual structure of those that rely on social welfare and those that rely on welfare provided by the market.

Conservative welfare state regimes maintain the difference in social stratification by providing welfare centered on social insurance. During the process of adapting to postindustrial social class structure, the corporatist-statist heritage designed welfare entitlement in which the existing socioeconomic stratification 
was re-enforced instead of increasing market efficiency and merchandizing welfare. It also restricted private insurance to a peripheral role when it came to welfare. The welfare system was aimed at maintaining the values and structure of the traditional family, in which one male breadwinner took care of the entire family. Women received family allowances through the male breadwinner, and the development in family services, such as daycare services that increased women's economic activity, were unlikely. Corporatist welfare state regimes do have the ability to replace the market in providing welfare but, according to the principle of subsidiarity, the state only intervenes when the traditional breadwinner fails to provide welfare to family members.

Social democratic welfare state regimes not only provide universal welfare to their entire citizenry but also aim to establish social solidarity by expanding the principle of de-commodification to the new middle class. Social democratic welfare state regimes do not allow for the existence of the dual structure of statemarket, or working class-middle class, and achieve high de-commodification effects and equality because the state provides allowances proportional to income based on a unitary insurance system provided to all citizens. Welfare policies are focused on social services, where daycare services led by a public sector that incentivizes women to participate in economic activities and acts as a main source of jobs for women. Furthermore, social democratic welfare state regimes intend to cover the enormous costs of maintaining solidarity within a universal, de-commodification-driven welfare system by achieving full employment and combining welfare and labor.

What conclusion can be drawn by analyzing Figure 10 with the welfare state regime categories presented by Esping-Andersen? Among our target countries, those that fall within the category of liberal market economies (Australia, Canada, New Zealand, the United Kingdom, and the United States) can also be grouped into liberal welfare state regimes. Among the coordinated market economies, Germany, Belgium, Austria, and the Netherlands can be categorized as conservative welfare state regimes, while Denmark, Finland, Norway and Sweden can be categorized as social democratic welfare state regimes. Even when separating the conservative welfare state regimes and social democratic welfare state regimes on the left panel of Figure 10, there are no differences in the relationship between inequality and redistribution. The two welfare state regimes show near parallel lines when it comes to the relationship between inequality and redistribution. Thus, when looking at the relationship between inequality and redistribution by separating the countries into liberal-corporatist-social democratic welfare state regimes, no clear differences between the three can be found. 
Figure 11. Varieties of Capitalism, Inequality, and Social Spending
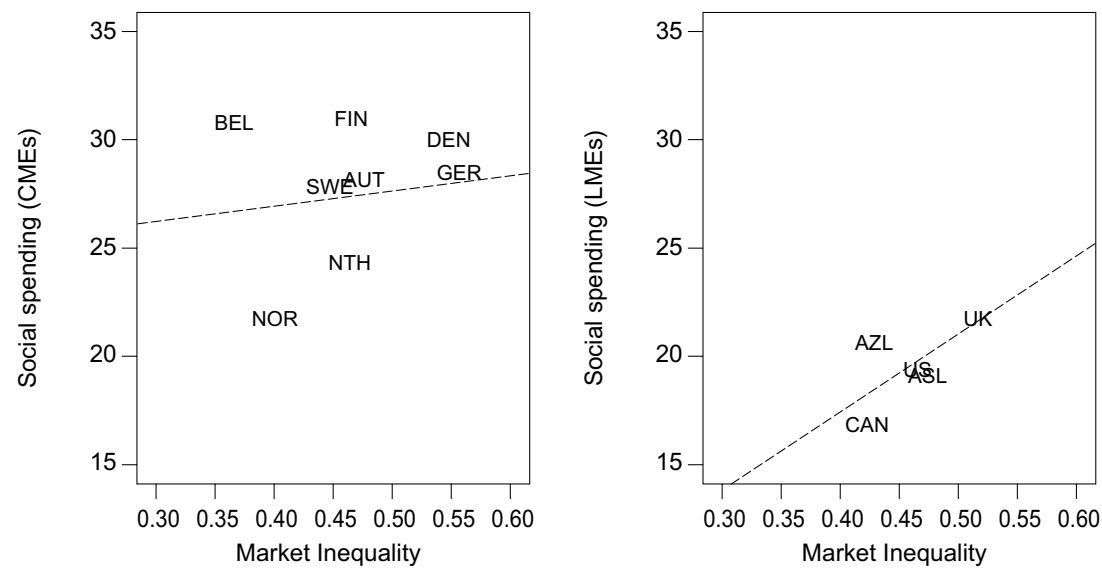

Figure 11 shows the relationship between income inequality and social spending. While in coordinated market economies no clear pattern was found in the relationship between inequality and social spending, under liberal market economies there was a positive correlation between inequality and social spending. However, it would be wise to refrain from making hasty conclusions, considering that the analysis is based on only five cases. On the other hand, when evaluating Figure 11 from the perspective of the three types of welfare states, an interesting pattern can be found. Countries categorized under conservative welfare state regimes, such as Belgium, Austria, the Netherlands, and Germany on the left panel, show a negative correlation between inequality and social spending. On the other hand, social democratic welfare state regimes such as Denmark, Finland, Norway, and Sweden show a positive correlation between inequality and social spending. Thus, in liberal welfare state regimes and social democratic welfare state regimes, inequality and social spending show a positive correlation, while in conservative welfare state regimes the correlation is shown to be negative.

\section{CONCLUSION}

This paper has shown an exploratory analysis based on empirical data of the trends and patterns of income inequality, redistribution policies and social policy outcomes in advanced democratic countries. Advanced democratic countries commonly saw a dramatic increase in income inequality since the 1980 s. 
Regardless, there are differences across countries, where income inequality of full-time workers and households were dramatically severe in some and relatively low in others. This paper has also analyzed the patterns among inequality, redistribution, and social spending based on existing theories. Utilizing the Meltzer-Richard model based on the median voter theorem and its empirical counter-examples of the 'paradox of redistribution,' government partisanship theory, electoral systems, 'varieties of capitalism' and welfare state regime theory, this paper has presented an analysis of the empirical patterns of inequality, redistribution, and social policies provided by recent data.

The results of our exploratory analysis have shown that the negative association between wage inequality (among full-time workers), redistribution and social spending supports the paradox of redistribution argument. However, the positive relationship between household income inequality and redistribution/social spending suggests supporting evidence for the Meltzer-Richard model. Using both the left government partisanship measure and right government partisanship measure, we found a strong relationship between government partisanship and redistributive and social policy outcomes. Unlike the decline-of-partisanship argument, we observe the partisanship effect is still at work. However, we did not find supporting patterns of the electoral system effect and the varieties-of-capitalism effect on the relationship between inequality and redistribution/social spending outcomes. Our analysis also suggests that conservative welfare state regimes show a negative association between inequality and social spending, whereas there is a positive relationship between inequality and social spending in both liberal and social democratic welfare state regimes.

This paper has presented and analyzed patterns and trends of recent data on inequality, redistribution, and social spending of advanced democratic countries. By uncovering empirical patterns based on the data, this paper has suggested several important and interesting points for further investigation. Thus, the limits and direction of future research presented by this paper are relatively clear. First, this paper mainly used scatter plots to present the patterns of relationships between inequality, redistribution, and social spending, which pose limits due to the number of cases and the use of bivariate regression (or simple correlation). Second, regardless of such limits, future research could yield interesting insights if theoretical hypotheses could be derived from the exploratory analysis of the trends and patterns of inequality and redistribution, and if such hypotheses could be tested systematically. 


\section{REFERENCES}

Allan, James, and Lyle Scruggs. 2004. "Political Partisanship and Welfare State Reform in Advanced Industrial Societies." American Journal of Political Science 48(3), 496-512.

Bradley, David, Evelyn Huber, Stephanie Moller, Francois Nielson, and John D. Stephens. 2003. "Distribution and Redistribution in Postindustrial Democracies." World Politics 55(2), 193-228.

Emmenegger, P., S. Husermann, B.Palier, and M. Seeleib-Kaiser, M. eds. 2012. The Age of Dualization: The Changing Face of Inequality in De-industrializing Societies, New York: Oxford University Press.

Esping-Andersen, Gøsta. 1990. The Three Worlds of Welfare Capitalism. Princeton: Princeton University Press.

. 1999. Social Foundations of Postindustrial Societies. Princeton: Princeton University Press.

Estevez-Abe, Margarita, TorbenIversen, and David Soskice. 2001. "Social Protection and the Formation of Skills: A Reinterpretation of the Welfare State." In Peter A. Hall and David Soskice eds., Varieties of Capitalism: The Institutional Foundations of Comparative Advantage. New York: Oxford University Press, 145-183.

Garrett, Geoffrey. 1998. Partisan Politics in the Global Economy. New York: Cambridge University Press.

Hall, Peter, and David Soskice. 2001. "Introduction.” In Peter A. Hall and David Soskice eds. Varieties of Capitalism: The Institutional Foundations of Comparative Advantage. Oxford: Oxford University Press, 1-68.

Hibbs, Douglass, Jr. 1977. "Political Parties and Macroeconomic Policy." American Political Science Review 71(4), 1467-1487.

Huber, Evelyn, and John Stephens. 2001. Development and Crisis of the Welfare State. Chicago: University of Chicago Press.

Iversen, Torben, and David Soskice. 2006. "Electoral Institutions and the Politics of Coalitions: Why Some Democracies Redistribute More than Others." American Political Science Review 100(2), 165-182.

. 2009. "Distribution and Redistribution: The Shadow of the Nineteenth Century." World Politics 61(3), 438-486.

Kenworthy, Lane, and Jonas Pontusson. 2005. "Rising Inequality and the Politics of Redistribution in Affluent Countries." Perspectives on Politics 3(3), 449-471.

Korpi, Walter. 1983. The Democratic Class Struggle. London: Routledge and Kegan Paul. 
. 2006. "Power Resources and Employer-Centered Approaches in Explanations of Welfare States and Varieties of Capitalism." World Politics 58(2), 167-206.

Korpi, Walter, and Joakim Palme. 2003. "New Politics and Class Politics in the Context of Austerity and Globalization." American Political Science Review 97(3), 425-446.

Kwon, Hyeok Yong, and Jonas Pontusson. 2010. "Globalization, Labour Power and Partisan Politics Revisited.” Socio-Economic Review 8(2), 251-281.

Lupu, Noam, and Jonas Pontusson. 2011. "The Structure of Inequality and the Politics of Redistribution.” American Political Science Review 105(2), 316-336.

Meltzer, Alan H., and Scott F. Richard. 1981. "A Rational Theory of the Size of Government.” Journal of Political Economy 89(5), 914-927.

Moene, Karl Ove, and Michael Wallerstein. 2001. "Inequality, Social Insurance, and Redistribution.” American Political Science Review 95(4), 859-874. . 2003. "Earnings Inequality and Welfare Spending." World Politics 55, 485-516.

OECD. 2015. Social Expenditure Database. Paris: OECD.

Pontusson, Jonas. 2005. Inequality and Prosperity: Social Europe vs. Liberal America. Ithaca, NY: Cornell University Press. . 2013. "Unionization, Inequality and Redistribution." British Journal of Industrial Relations 51(4), 797-825.

Rueda, David. 2005. "The Insider-Outsider Politics in Industrialized Democracies: The Challenge to Social Democratic Parties.” American Political Science Review 99(1), 61-74. . 2007. Social Democracy Inside Out. Oxford: Oxford University Press.

Rueda, David, and Jonas Pontusson. 2000. "Wage Inequality and Varieties of Capitalism.” World Politics 52(3), 350-383.

Solt, Frederick. 2014. Standardized World Income Inequality Database.

Wallerstein, Michael. 1999. "Wage-Setting Institutions and Pay Inequality in Advanced Industrial Societies.” American Journal of Political Science 43(3), 649-680. 